\title{
Proceeding
}

8th INSHS International Christmas Sport Scientific Conference, 5-7 December 2013. International Network of Sport and Health

Science. Szombathely, Hungary

\section{Function of motor system at students of Sports Management university}

\author{
PETR HRUSA $\triangle$, DAGMAR HRUSOVA \\ ${ }^{1}$ Department of Recreology and Tourism, Faculty of Informatics and Management, University of Hradec Kralove, \\ Czech Republic.
}

\begin{abstract}
Hrusa, P. \& Hrusova, D. (2014). Function of motor system at students of Sports Management university. J. Hum. Sport Exerc., 9(Proc1), pp.S236-S244. The research focused on motor system function of students of bachelor's studies of sports management, a young field of study which is characterised by a dynamic development. The course made demands both on theoretical knowledge and practical skills and the students get through modules of bio-medical, kinanthropological and economic-managerial disciplines concerning theory, and fitness-wellness, outdoor and games modules concerning practice. We work on an analysis of sports management study curriculum and consequent requirements in accord with recent research in the field of changes in function of motor system. The aim of the study is to examine the function of motor system. It was assumed that students of sports management studies have an optimal function of their motor system. The problem was solved by an empirical research approach both with qualitative data analysis; a sample comprising 30 subjects - sports management students (10 women, 20 men) - was examined. As indicators of the function we followed muscle function (local and global stabilizers), flexibility, and posture. Somatoscopic and somatometric diagnostic tools based on methods of measurement and observation; techniques of ordinal scale, check-list and alternative score were employed. The data were analysed by qualitative analysis based on a consensus of expert opinions. A comprehensive diagnostic was completed of the functional level of motor system (11 tests of local stabilizing muscle function, 5 tests of global stabilizing muscle function, 9 tests of flexibility and 2 indicators of posture). It was verified that the function is optimal at the sports management students. Optimal function is related to effective muscle involvement and adequate stabilization during motion. Such motor-functional preparedness is beneficial for sports management students to cope with their study load. Key words: MUSCULAR-SKELETAL SYSTEM, SPORTS, OPTIMAL FUNCTION, CHANGES IN FUNCTION.
\end{abstract}

\footnotetext{
Corresponding author. Department of Recreology and Tourism, Faculty of Informatics and Management,

University of Hradec Kralove, Czech Republic.

E-mail: hedbavny@fsps.muni.cz

8th INSHS International Christmas Sport Scientific Conference, 5-7 December 2013. International Network of Sport and Health Science. Szombathely, Hungary.

JOURNAL OF HUMAN SPORT \& EXERCISE ISSN 1988-5202

(c) Faculty of Education. University of Alicante

doi:10.14198/jhse.2014.9.Proc1.04
} 


\section{INTRODUCTION}

According to the defined profile, a sports management graduate is a competent, modern and long-term competitive creative expert in management and marketing in the field of sport, leisure and recreation. Graduates find employment in management and marketing (sports clubs, associations and organizations, sports centres), tourism (experience tourism, outdoor programmes, and fitness-wellness programmes), services and facilities offering sports and recreation products, and in wellness and health resort (Hruša \& Hrušová, 2012). Sports manager's education includes both theory and practice. In the field of practice Pưža \& Komeštík (2012) emphasize, in accord with the current trend (social need and demand for more attractive and more intense experiences in leisure, recreation and tourism), focus on sports activities, which are based on positive and meaningful experiences, proving one's own physical and mental strength, taking load, and the resulting satisfaction of performance. Optimal motor-functional preparedness of the musculoskeletal system is an essential precondition for an effective involvement of the deep stabilization system (stabilization of spine and major joints), and effective movement (locomotive function).

Currently, the number of hours spent sitting at majority of people is increasing and volume and frequency of active movement is decreasing (hypokinesis). Along with other factors, this may cause disrupting of the functional balance of musculoskeletal system. The imbalances often result in changed patterns of muscle involvement in stereotypes, changed muscular coordination, formation of incorrect stereotypes, tightened or weakened muscles, and changes in posture. Unlike the general population, however, sport management students spend more time doing sport, based on the analysis of the curriculum and the consequent requirements. The course makes demands on both theoretical knowledge and practical skills. The students get through modules of bio-medical, kinanthropological and economic-managerial disciplines concerning theory, and fitness-wellness, outdoor and games modules concerning practice. The aim of this research study was to evaluate the function of musculoskeletal system at students of sports management at the selected universities, with focus on local stabilizers, global stabilizers, flexibility, and posture, in relation to an optimal motor-functional preparedness of the musculoskeletal system.

The basic function of musculoskeletal system is to perform movements and maintain posture. Individual parts of human body should co-operate in perfect harmony and balance, in holistic approach. Functional disorders are a common cause of pain, and vice versa, pain is one of the most important factors influencing muscle function. Pains that occur without pathological, structural findings, are referred to as non-specific or idiopathic (van Tulder et al., 1997; Trnavský, 2006), in other words, without diagnosis (Kolár \& Lewit, 2005). Lewit (1990) reported that almost $90 \%$ of painful musculoskeletal disorders are classified as non-specific pain. One can be limited by the perception of pain in everyday activities, which can affect the quality of routine movements, thereby further aggravate the disorders. This is also supported by Swinkels et al. (2009) in "fear avoidance model", explaining the effect of fear of pain on exercise regime.

For diagnostic and therapeutic purposes Koláŕ (1997) sets three major musculoskeletal system levels of functional disorders manifestation - central neural regulation, muscles and joints. In diagnostic and therapy it is important to be aware of the joint and muscle synergy, which means that changes in joint affect muscle function and vice versa.

Adaptive changes in muscle function are manifested either by tightness or weakness of the muscles. Accordingly, they can be divided into two groups: local and global stabilizers. The author of the systemization is Janda, as quoted e.g. by Koláŕ (2001). Local stabilizers have postural function, tend to be hyperactive, and substitute for the weakened muscles. They are hypertonic, their rest length can be 
shortened and deviate the joint from the neutral position. These muscles have predominance of red muscle fibers innervated predominantly by small $\alpha$-motor neurons. Global stabilizers are less activated, subject to involution and tend to be weakened. These muscles have predominance of white muscle fibers innervated predominantly by large $\alpha$-motor neurons. The difference between local and global stabilizers is also in their postural integration (Kolár, 2001). Global stabilizers are younger in their postural function, from the phylogenetic or ontogenetic view, than local stabilizers. The above-described adaptive changes - functional disorders - often occur in typical combinations, especially in the shoulder and pelvic girdle. These muscle imbalances have their clinical significance and Janda (1974) describes them as syndromes - upper crossed syndrome and lower crossed syndrome.

Upper crossed syndrome combines tightness and weakness that occurs in the shoulder girdle. Tightness of upper trapezius and musculus $(\mathrm{m}$.) levator scapulae crosses with tightness of $\mathrm{m}$. pectoralis major and minor. Weakness of deep cervical flexors crosses with weakness of middle and lower trapezius. Lower crossed syndrome combines tightness and weakness that occurs in the pelvic girdle (lower back, core, and hip muscles). Tightness of thoracolumbar extensors crosses with tightness of hip flexors. Weakness of deep abdominal muscles crosses with weakness of $\mathrm{m}$. gluteus maximus and medius.

The function of the joint can be affected by two basic types of disorders: increased joint mobility (hypermobility), with greater pathological significance (Kolár̆, 1997), and limited joint mobility. Both active and passive movement (joint blockade - Kolár, 1997) can be limited. According to Lewit (1990), a joint blockade of one of the most significant functional disorders in musculoskeletal system, as major causes there is overloading due to motor stereotypes disorders, overloading, an injury or reflective way.

As mentioned above, the basic function of the musculoskeletal system is to perform movements and maintain posture. Theoretical concepts concerning posture (e. g. Kolář et al., 2009; Véle, 1995; Vařeka, 2002; Riegerová, 2006) agree that from a biomechanical point of view, the ideal is upright posture, which meets the energy-economic demands. Upright posture has large compensatory and substitution possibilities (Vařeka, 2002). However, limitation in function or weakening of any of its parts can result in decompensation, which may not occur immediately, but for example in a situation of increased loading. This risk also exists for the students of sports management, the subject of this research study. It is due to a large volume of physical loading in the curriculum of sports management. Among other risk factors in changes in function of musculoskeletal system there is a lack of movement (hypokinesy), or incorrect technique of movement (stereotypes) and influence of one-sided, uncompensated load. Individually optimal posture requires effective involvement of stabilizing (postural) muscle function both in dynamic and static situations (Riegerová, 2006). It is necessary to be aware that posture can be affected by psychological processe. Vařeka (2002), Kolář et al. (2009), Leeuw et al. (2007), and Symonds et al. (1995) agree that certain concentration improves postural stability; however, an excessive mental stress aggravates it.

\section{MATERIAL AND METHODS}

The study is focused on musculoskeletal system, its function and changes in function (disorders) at the sports management students. Curriculum and consequent requirements of sports managements were analyzed with reference to recent research in the field of changes in function of musculoskeletal system. The aim of the study was to examine and evaluate the function of musculoskeletal system at sports management students, with regard to muscle function (local stabilizers, global stabilizers), flexibility, and posture. It was assumed that students of sports management studies have an optimal function of their 
musculoskeletal system. The problem was solved by an empirical approach with qualitative data analysis, based on expert opinions.

\section{Participants}

Research sample comprised 30 participants (10 women, 20 men), selected by a deliberate statistical choice. All the participants were students of sports management studies at the selected universities (University of Hradec Kralove, Masaryk University Brno). A preliminary anamnesis was done for basic characteristics of the research sample, focusing on the following dimensions: a weekly physical activity (frequency, volume and type of the activity), the number of hours a day spend sitting, implementation of stretching and compensation exercises in training, long-term health condition, acute or chronic musculoskeletal pain, injury or rehabilitation in the past 6 months.

\section{Measures}

The qualitative methods of content analysis and synthesis were used to review relevant sources to set the convenient theoretical and methodological bases. Questionning was used as a method for deliberate selection of the participants - a technique of interview (anamnestic). Participants were measured to obtain the basic somatometric data (body weight, body height, and body mass index).

A comprehensive diagnostic was completed of the function of musculoskeletal system: 11 tests of local stabilizing muscle function, 5 tests of global stabilizing muscle function, 9 tests of flexibility, and 2 indicators of posture. Somatoscopic and somatometric diagnostic tools based on methods of measurement and observation; techniques of ordinal scale, check-list and alternative score, were employed. The selected diagnostic tools are standardized in procedures and are commonly used in diagnostic in clinical practice. Regarding the local stabilizing muscle function, the following muscles were examined (Janda, 2004): musculus (m.) triceps surae, hip joint flexors, knee joint flexors, hip joint adductors, m. piriformis, $\mathrm{m}$. quadratum lumborum, $\mathrm{m}$. pectoralis major, $\mathrm{m}$. trapezius (pars descendens), $\mathrm{m}$. levator scapulae, $\mathrm{m}$. sternocleidomastoideus, and paravertebrae back muscles. It was differentiated between optimal function ("0"), minor tightness ("1"), and major tightness ("2"). Regarding the global stabilizing muscle function, the following muscles were examined (Janda, 2004): m. gluteus maximus, m. rectus abdominis, deep head and neck flexors, $\mathrm{m}$. deltoideus, and $\mathrm{mm}$. rhomboidei. It was differentiated between optimal function ("0"), and minor weakness ("1"). Regarding the flexibility, the following indicators were employed (Janda, 2004: head rotation, arms stretched backwards, folded arms, trunk bent sideways, extended elbows, clasped hands, clasped fingers, trunk bent forwards, and kneeling sitting on heels. It was differentiated between optimal ("0") and increased ("+") or decreased ("-") flexibility. Regarding the posture, two indicators were employed: posture evaluation according to Klein, Thomas, and Mayer (in Haladová \& Nechvátalová, 1997) - by aspection from the front, from the side and from behind, and posture examination according to Mathias (in Haladová \& Nechvátalová, 1997) - hold of the upright stand with arms stretched forward for 30 seconds. The quality of postural stereotypes was evaluated on the scale $A, B, C, D$ in Klein, Thomas, and Mayer diagnosis ( $A$ and $B$ regarded as optimal function for data analysis). In Mathias diagnosis it was differentiated between optimal postural function ("0") and declined function ("1").

\section{Analysis}

Data were processed and evaluated in qualitative analysis according to the criteria based on the consensus of expert opinions $(n=3)$. These criteria were established by determination of the minimum relative frequency of optimal function in the sample in individual indicators. $70 \%$ of cases with optimal function were required for verification of the partial hypotheses. An optimal function was referred to as more than 50 
$\%$ of muscles being optimal in the given indicator (local stabilizing function, global stabilizing function, flexibility, and posture).

\section{RESULTS}

\section{Local stabilizing muscles}

In table 1 it is showed that the condition of minimum relative frequency of $70 \%$ of cases with optimal function was not fulfilled only in 2 partial tests of muscle function (m. sternocleidomastoideus - $33 \% \mathrm{~L}, 27$ $\%$ R minor tightness, $7 \%$ L, $7 \%$ R major tightness; paravertebrae back muscles - $47 \%$ minor tightness and $3 \%$ major tightness). The set criterion was exceeded in 9 of 11 cases (82\%); values of insufficient function according to the criteria are marked red in table 1 . The results also showed that the right and left side were relatively balanced, and if tightness was diagnosed, it was a minor tightness in most cases. The results appear to suggest that the sports management students have optimal function of local stabilizers muscles with tendency to tightness.

Table 1. Results of tests of local stabilizing function

\begin{tabular}{|c|c|c|c|c|c|c|c|c|c|c|c|c|}
\hline \multirow{4}{*}{ Local stabilizers } & \multicolumn{12}{|c|}{ Scale } \\
\hline & \multicolumn{4}{|c|}{0} & \multicolumn{4}{|c|}{1} & \multicolumn{4}{|c|}{2} \\
\hline & \multicolumn{2}{|c|}{$L$} & \multicolumn{2}{|c|}{$\mathbf{R}$} & \multicolumn{2}{|c|}{$L$} & \multicolumn{2}{|c|}{$\mathbf{R}$} & \multicolumn{2}{|c|}{$L$} & \multicolumn{2}{|c|}{$\mathbf{R}$} \\
\hline & Abs. & Rel. & Abs. & Rel. & Abs. & Rel. & Abs. & Rel. & Abs. & Rel. & Abs. & Rel. \\
\hline m. triceps surae & 27 & 0.9 & 27 & 0.9 & 3 & 0.1 & 3 & 0.1 & 0 & 0 & 0 & 0 \\
\hline hip joint flexors & 24 & 0.8 & 24 & 0.8 & 4 & 0.13 & 5 & 0.17 & 2 & 0.07 & 1 & 0.03 \\
\hline knee joint flexors & 25 & 0.83 & 25 & 0.83 & 4 & 0.13 & 4 & 0.13 & 1 & 0.03 & 1 & 0.03 \\
\hline hip joint adductors & 23 & 0.77 & 22 & 0.73 & 5 & 0.16 & - & 0.23 & 2 & 0.07 & 1 & 0.33 \\
\hline m. piriformi & 25 & 0.83 & 26 & 0.87 & 5 & 0.17 & 4 & 0.13 & U & 0 & 0 & 0 \\
\hline m. quadratus lumborum & 27 & 0.9 & 27 & 0.9 & 3 & 0.1 & 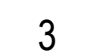 & 0.1 & 0 & 0 & 0 & 0 \\
\hline m. pectoralis major & 26 & 0.87 & 25 & 0.83 & 4 & 0.13 & 5 & 0.17 & 0 & 0 & 0 & 0 \\
\hline $\begin{array}{l}\text { m. trapezius - pars } \\
\text { descendens }\end{array}$ & 24 & 0.8 & 25 & 0.83 & 6 & 0.2 & 5 & 0.17 & 0 & 0 & 0 & 0 \\
\hline m. levator scapulae & 25 & 0.83 & 24 & 0.8 & 5 & 0.17 & 6 & 0.2 & 0 & 0 & 0 & 0 \\
\hline \multirow[t]{3}{*}{ m. sternocleidomastoideus } & 18 & 0.6 & 20 & 0.67 & 10 & 0.33 & 8 & 0.27 & 2 & 0.07 & 2 & 0.07 \\
\hline & \multicolumn{4}{|c|}{$L+R$} & \multicolumn{4}{|c|}{$L+R$} & \multicolumn{4}{|c|}{$L+R$} \\
\hline & \multicolumn{2}{|c|}{ Abs. } & \multicolumn{2}{|c|}{ Rel } & \multicolumn{2}{|c|}{ Abs. } & \multicolumn{2}{|c|}{$\operatorname{Re}$} & $A$ & & \multicolumn{2}{|c|}{ Rel. } \\
\hline paravertebrae back muscles & \multicolumn{2}{|c|}{15} & \multicolumn{2}{|c|}{0.5} & 1 & 4 & \multicolumn{2}{|c|}{0.47} & 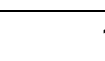 & & \multicolumn{2}{|c|}{0.03} \\
\hline
\end{tabular}


Table 2. Results of tests of global stabilizing function

\begin{tabular}{lcccc}
\hline \multirow{1}{*}{\multicolumn{1}{c}{ Global stabilizers }} & \multicolumn{4}{c}{ Scale } \\
\cline { 2 - 5 } & \multicolumn{3}{c}{$\mathbf{0}$} & \multicolumn{3}{c}{$\mathbf{1}$} \\
\cline { 2 - 5 } & Abs. & Rel. & Abs. & Rel. \\
\hline m. gluteus maximus & 25 & 0.83 & 5 & 0.17 \\
m. rectus abdominis & 17 & 0.57 & 13 & 0.43 \\
deep head and neck flexors & 22 & 0.73 & 8 & 0.27 \\
m. deltoideus & 21 & 0.7 & 9 & 0.3 \\
mm. rhomboidei & 24 & 0.8 & 6 & 0.2 \\
\hline
\end{tabular}

Table 3. Results of tests of flexibility

\begin{tabular}{|c|c|c|c|c|c|c|c|c|c|c|c|c|}
\hline \multirow{4}{*}{ Tests of flexibility } & \multicolumn{12}{|c|}{ Scale } \\
\hline & \multicolumn{4}{|c|}{ Optimal } & \multicolumn{4}{|c|}{ "+" } & \multicolumn{4}{|c|}{ "-" } \\
\hline & \multicolumn{2}{|c|}{$\mathrm{L}$} & \multicolumn{2}{|c|}{$\mathbf{R}$} & \multicolumn{2}{|c|}{$\mathrm{L}$} & \multicolumn{2}{|c|}{$\mathbf{R}$} & \multicolumn{2}{|c|}{$\mathrm{L}$} & \multicolumn{2}{|c|}{$\mathbf{R}$} \\
\hline & Abs. & Rel. & Abs. & Rel. & Abs. & Rel. & Abs. & Rel. & Abs. & Rel. & Abs. & Rel. \\
\hline \multirow{6}{*}{$\begin{array}{l}\text { head rotation } \\
\text { arms } \\
\text { backwards } \\
\text { folded arms } \\
\text { trunk bent sideways }\end{array}$} & 30 & 1 & 30 & 1 & 0 & 0 & 0 & 0 & 0 & 0 & 0 & 0 \\
\hline & 20 & 0.67 & 22 & 0.73 & 1 & 0.03 & 1 & 0.03 & 9 & 0.3 & 7 & 0.24 \\
\hline & 29 & 0.97 & 28 & 0.93 & 1 & 0.03 & 2 & 0.07 & 0 & 0 & 0 & 0 \\
\hline & 30 & 1 & 30 & 1 & 0 & 0 & 0 & 0 & 0 & 0 & 0 & 0 \\
\hline & \multicolumn{4}{|c|}{$L+R$} & \multicolumn{4}{|c|}{$L+R$} & \multicolumn{4}{|c|}{$L+R$} \\
\hline & \multicolumn{2}{|c|}{ Abs. } & \multicolumn{2}{|c|}{ Rel. } & & ss. & \multicolumn{2}{|c|}{ Rel. } & & ss. & \multicolumn{2}{|c|}{ Rel. } \\
\hline extended elbows & \multicolumn{2}{|c|}{30} & \multicolumn{2}{|c|}{1} & & jo & \multicolumn{2}{|c|}{0} & & jo & \multicolumn{2}{|c|}{0} \\
\hline clasped hands & \multicolumn{2}{|c|}{30} & \multicolumn{2}{|c|}{1} & & b & \multicolumn{2}{|c|}{0} & & b & \multicolumn{2}{|c|}{0} \\
\hline clasped fingers & \multicolumn{2}{|c|}{29} & \multicolumn{2}{|c|}{0.97} & & 0 & \multicolumn{2}{|c|}{0} & & 1 & \multicolumn{2}{|c|}{0.03} \\
\hline trunk bent forwards & \multicolumn{2}{|c|}{26} & \multicolumn{2}{|c|}{0.87} & & 4 & \multicolumn{2}{|c|}{0.13} & & 0 & \multicolumn{2}{|c|}{0} \\
\hline kneeling sitting on heels & & 8 & & 6 & & 2 & & 07 & & 0 & & 33 \\
\hline
\end{tabular}

\section{Global stabilizing muscles}

Results in table 2 show that that the condition of minimum relative frequency of $70 \%$ of cases with optimal function was not fulfilled only in 1 partial test of muscle function (m. rectus abdominis - $83 \%$ weakness). The set criterion was exceeded in 4 of 5 cases ( $80 \%$ ). The results appear to suggest that the sports management students have optimal function of global stabilizers - muscles with tendency to weakness.

\section{Flexibility}

Table 3 shows that in majority of tests of flexibility the sports management students did not have problem to meet the requirement for optimal function. Condition of the minimum relative frequency of $70 \%$ of the cases with optimal function was not fulfilled only in 2 partial tests of flexibility (kneeling sitting on heels - 60 $\%$, arms stretched backwards - $67 \%$ L). The set criterion was exceeded in 7 of 9 cases $(77 \%)$; values of 
insufficient function according to the criteria are marked red in table 3. The results appear to suggest that the sports management students have optimal active flexibility.

Table 4. Results of tests of postural stereotypes

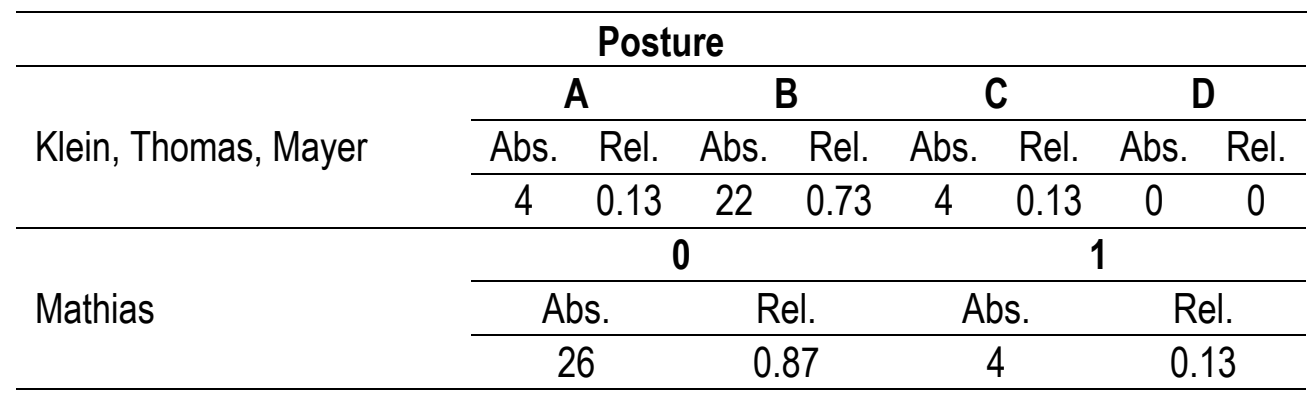

\section{Posture}

As shown in table 4, both selected indicators of posture (100\%) exceeded the minimum relative frequency of $70 \%$ of cases with optimal function. Specifically 26 participants $(87 \%)$ were evaluated with optimal function, in both tests of postural stereotypes. Only at 4 subjects the posture was evaluated as poor, the results were consistent in both tests (validity by parallel criteria). The results appear to suggest that the sports management students have optimal posture.

The total results suggest that the students of sports management have optimal function of musculoskeletal system, with regard to the set conditions of verification.

\section{DISCUSSION}

Using the selected indicators function of musculoskeletal system were examined and evaluated at students of sports management. All participants were active athletes. The average volume of physical activity was 12 hours a week in leisure time and 11 hours a week within the practice in the study curriculum. The participants' BMI was normal and the health condition was good. Even though, $23 \%$ of participants suffered from occasional chronic non-specific low back pain. Authors agree that the boundary between the acute and chronic stage is considered a period of three months (Taylor et al., 2011; Andersson, 1999; Grotle et al., 2004; Slade \& Keating, 2006; Trnavský, 2006). Not only physical, but also psychological factors (such as fatigue, depression, anxiety, long-term psychological stress, low pain threshold or inability to cope with the disease) can influence the transition between acute and chronic stage (Burton et al., 1996; Smedley et al., 2005). According to Kolář \& Lewit (2005) approximately $70 \%$ of adults have ever suffered from back pain and at the same time repeated episodes of the low back pain are one of the most expensive healthcare problems (Hides et al., 2001). The findings of this study point to the possibility of functional relation of low back pain with insufficient function of abdominal muscles (43\% weakness), decreased flexibility in the test of kneeling sitting on heels (33\%), and also with the change in function of paravertebrae back muscles (50\%). With regard to a lower crossed syndrome (Janda, 1974) the findings of the study appear to reflect frequently occurring imbalance in the pelvic girdle, regarding the evaluated changes in function: weakness of abdominal muscles, tightness of hip flexors, and tightness of low back muscles. This can be supported by Lewit \& Kolár (2005) who suggest functional disorders in spine stabilizers as one of major etio-pathogenetic factors of low back pain. However, it is noteworthy that the weakening of abdominal muscles was found right at the active athletes. As a diagnostic tool of muscle 
function in this research study, the test of strength of abdominal muscles was used, like in the research of Kloubec et al. (2010), O'Brien et al. (2006) Emery et al. (2010) and others. For further research it can be suggested to focus also on the level of coordination and muscle involvement in motor stereotypes, in agreement with the findings of Segal et al. (2004). However, despite the above discussed changes in muscle function, with regard to the total results and the set criteria, it can be summarized that the function of musculoskeletal system (local stabilizers, global stabilizers, flexibility, and posture) at the selected students of sports management was optimal.

\section{CONCLUSIONS}

The data were analysed by qualitative analysis based on a consensus of expert opinions. A comprehensive diagnostic was completed of the function of motor system (11 tests of local stabilizing muscle function, 5 tests of global stabilizing muscle function, 9 tests of flexibility and 2 indicators of posture). The total results suggest that the students of sports management have optimal function of musculoskeletal system, with regard to the set conditions of verification. Optimal function is related to effective muscle involvement and stabilization during motion. Such motor-functional preparedness is beneficial for sports management students to cope with their study load.

\section{ACKNOWLEDGEMENT}

The authors would like to thank Katerina Juzova for her great help and co-operation in the examination and evaluation of the function of musculoskeletal system.

\section{REFERENCES}

1. Andersson, G.B. (1999). Epidemiological features of chronic low-back pain. Lancet, 354(9178), pp.581-585.

2. Burton, A.K. et al. (1996), Occupational risk factors for the first-onset and subsequent course of low back trouble. A study of servis police officers. Spine, 21(22), pp.2612-2620.

3. Emery et al. (2010). The effects of a Pilates training program on arm-trunk posture and movement. Clinical Biomechanics, 25(2), pp.124-130.

4. Grotle, M. et al. (2004). Fear-avoidance beliefs and mistress in relation to disability in acute and chronic low back pain. Pain, 112(3), pp.343-352.

5. Haladová, E. \& Nechvátalová, L. (1997). Vyšetřovací metody hybného systému. Brno: Institut pro další vzdělávání pracovníků ve zdravotnictví.

6. Hruša, P. \& Hrušová, D. (2013). Sports gymnastics as a part of curriculum of Sports Management university studies in the Czech Republic. J Hum Sport Exerc, 8(2), pp.107-113.

7. Janda, V. et al. (2004). Svalové funkční testy. Praha: Grada.

8. Janda, V. (1974). Vyšetřování hybnosti [I]. Praha: Avicenum.

9. Kloubec, J.A. (2010). Pilates for improvement of muscle endurance, flexibility, balance, and posture. J Strength Cond Res, 24(3), pp.661-667.

10. Kolář, P. (2009). Kineziologie páteře, pánve a hrudníku. pp.12-143. In KOLÁŘ, P. et al. Rehabilitace v klinické praxi. Praha: Galén.

11. Kolář, P. (2001). Systematizace svalových dysbalance z pohledu vývojové kineziologie. Rehabilitace a fyzikální lékařství, 4, pp.152-164.

12. Kolář, P. \& Lewit, K. (2005). Význam hlubokého stabilizačního systému v rámci vertebrogenních obtíźi. Neurologie pro praxi, 5, pp.270-275. 
13. Leeuw, M. et al. (2007). The fear-avoidance model of musculoskeletal pain: current state of scientific evidence. J Behav Med, 30, pp.77-94.

14. Lewit, K. (1990). Manipulační léčba v rámci léčebné rehabilitace. Praha: Nakladatelství dopravy a spojü.

15. O'Brien, N., Hanlon, M. \& Meldrum, D. (2006). Randomized Controlled Trial Comparing Physiotherapy and Pilates in the Treatment of Ordinary Low Back Pain. Physical Therapy Reviews. 11(3), pp.224-225.

16. Pưža, B., Komeštík, B. (2012). Sportovně rekreační aktivity v cestovním ruchu. Hradec Králové: Gaudeamus.

17. Riegerová, J. (2006). Držení těla. pp.151-162. In Riegerová, J., Přidalová, M., Ulbrichová, M. Aplikace fyzické antropologie v tělesné výchově a sportu: príručka funkční antropologie. Olomouc: Hanex.

18. Segal, N.A., Hein, J., Basford, J.R. (2004). The effects of pilates training on flexibility and body composition: an observational study. Arch Phys Med Rehab, 85(12), pp.1977-1981.

19. Slade, S.C., Keating, J.L. (2006). Trunk-strengthening exercises for chronic low back pain: a systematic review. J Manip Physiol Ther, 29(2), pp.163-173.

20. Smedley, J. et al. (2005). Epidemiological differences between back pain of sudden and gradual onset. J Rheumatol, 32(3), pp.528-532.

21. Swinkels, A. et al. (2009). Exercise Interventions for Non-specific Low Back Pain: An Overview of Systematic Reviews. Physical Therapy Reviews, 14(4), pp.247-259.

22. Symonds, T.L. et al. (1995). Absence resulting from low back trouble can be reduced by psychosocial intervention at the work place. Spine, 20(24), pp.2738-2745.

23. Taylor, L., Hay-Smith, E.J.C., Dean, S. (2011). Can clinical pilates decrease pain and improve fiction in people complaining of non-specific low back pain? A pilot study. New Zealand Journal of Physiotherapy, 39(1), pp.30-38.

24. Trnavský, K. (2006). Několik poznámek k bolestem dolních zad. Rehabilitace a fyzikální lékařství, 1, pp.42-43.

25. Van Tulder, M.W. et al. (1997). Method guidelines for systematic reviews in the cochrane collaboration Back Review Group for Spinal Disorders. Spine, 22, pp.2323-2330.

26. Vařeka, I. (2002). Posturální stabilita (II. část): Řízení, zajištění, vývoj, vyšetření. Rehabilitace a fyzikální lékařství, 4, pp.122-129.

27. Véle, F. (1995). Kineziologie posturálního systému. Praha: Karolinum. 